Jurnal Info Kesehatan

Vol.18, No.1, June 2020, pp.28-39

P-ISSN 0216-504X, E-ISSN 2620-536X

DOI: 10.31965/infokes.Vol18.Iss1.306

Journal homepage: http://jurnal.poltekeskupang.ac.id/index.php/infokes

R E S E A R C H

Open Access

\title{
Quality of Visit and Fulfillment Needs after Childbirth: Study on Postpartum Maternal Mortality
}

\author{
Mariana Ngundju Awang ${ }^{1 a^{*}}$, Dian Maria Kristin ${ }^{1 b}$ \\ ${ }^{1}$ Department of Midwifey, Poltekkes Kemenkes Kupang, Indonesia \\ a Email address: ramyakeyken@gmail.com \\ b Email address: diyankristin@gmail.com
}

Received: 11 November 2019

Revised: 24 June 2020

Accepted: 24 June 2020

\begin{abstract}
Most maternal deaths occur during the postpartum period so that childbirth health services play an important role in reducing maternal mortality rates from 6 hours to 42 days after giving birth. It is estimated that $69 \%$ of maternal deaths due to pregnancy occur after childbirth, and $50 \%$ of postpartum deaths occurred in the first 24 hours. The highest number of maternal deaths was found in East Sumba Regency which was 19 maternal deaths, 12 of which were maternal deaths during the puerperium. Maternal deaths in 2017 out of 9 , there were 5 postpartum mothers whereas the $3^{\text {rd }}$ postpartum visit was $91 \%$. The objective of this study is to determine the quality of puerperal visits and the fulfillment of the needs of puerperal women in East Sumba Regency in 2015-2018. This type of research is a qualitative research with a phenomenological study. Participants or informants in this study were the husband or family of all mothers who died postpartum in 2015-2018 and midwives who deal with these mothers during antenatal care, childbirth and postpartum as well as data analysis which is content analysis. The results showed that the quality of puerperal visits was still irregular, unsystematic and unfocused so that it was unable to detect postpartum problems early. Meeting the needs of mothers during childbirth is still incomplete, not detailed and does not routinely conduct head-to-toe examinations during postpartum visits. The conclusion of the study shows that the quality of the visit and the fulfillment of the needs of the postpartum mothers are related to maternal mortality during the postpartum period in East Sumba Regency.
\end{abstract}

Keywords: Postpartum maternal mortality, East Sumba, Waingapu, Kawangu, Mangili.

\footnotetext{
*Corresponding Author:

Mariana Ngundju Awang

Department of Midwifey, Poltekkes Kemenkes Kupang

R.A. Kartini I, Kelapa Lima, Kupang City, East Nusa Tenggara, Indonesia

Email: ramyakeyken@gmail.com

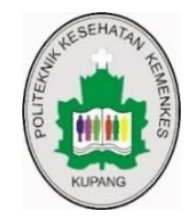

(C) The Author(s) 2020. This article is distributed under the terms of the Creative Commons Attribution 4.0 International License (http://creativecommons.org/licenses/by/4.0/), which permits unrestricted use, distribution, and reproduction in any medium, provided you give appropriate credit to the original author(s) and the source, provide a link to the Creative Commons license, and indicate if changes were made. The Creative Commons Public Domain Dedication waiver (http://creativecommons.org/publicdomain/zero/1.0/) applies to the data made available in this article, unless otherwise stated.
} 


\section{INTRODUCTION}

Maternal Mortality Rate (MMR) is one indicator of the results of development in the health sector, the lower the MMR the development of an area indicates the better development in the health sector. Maternal death is death that occurs during pregnancy, during childbirth, during the puerperium or two months after the end of pregnancy. The national maternal mortality rate tends to move fluctuatively, in the long run, which is in 2030, the maternal mortality rate is targeted to be less than 70 deaths per 100,000 live births (Kementerian Kesehatan R. I., 2018). In 2012, the maternal mortality rate increased to 359 per 100,000 live births and the 2015 AKI Inter-Census Survey (SUPAS) fell to 305 per 100,000 live births, which means that it exceeded the target in the 2015-2019 National Mid-Term Development Plan (RJPMN) of 306 per 100,000 live births but did not reach the Millennium Development Goals (MDGs) target of 102 per 100,000 live births (Rahmawati, E. \& Triatmaja, N, 2015) (Kementerian Kesehatan R.I., 2018).

The puerperium is still a vulnerable period for the survival of new birth mothers. According to a follow-up study of maternal deaths in 2010, most of the maternal deaths occurred in the puerperium so that postpartum health services play an important role in efforts to reduce maternal mortality. Postpartum care is health services provided to mothers during a period of 6 hours to 42 days or 6 weeks after giving birth. This period is an important period for health workers to always monitor because the implementation is less than the maximum which can cause mothers to experience various problems, even can lead to complications of the puerperal period, such as puerperal sepsis (Affandi, 2019).

Postpartum care is needed in this period because it is a critical period for both mother and baby. It is estimated that $69 \%$ of maternal deaths due to pregnancy occur after childbirth, and 50\% of postpartum deaths occur within the first 24 hours (Affandi, 2019); (Abdullah A, 2015); (Awang, 2017). Ministry of Health determines postpartum maternal contact or service program stated in the indicators: 1) Postpartum visit 1, postpartum maternal contact in the period of 6 hours to 8 hours after childbirth 2) postpartum visit 2, postpartum maternal contact on 6 days after childbirth and 3) postpartum visit 3, childbirth contact in the period 2 weeks after giving birth and childbirth visit 4, childbirth contact at 6 weeks after delivery (Kementerian Kesehatan R.I., 2013). According to the Indonesian Ministry of Health (2018), maternal health services obtained during 42 days after delivery, at least 3 times include: Postpartum visits 1 ( 6 hours to 3 days after delivery), postpartum visits 2 (4 to 28 days after delivery) and 3 parturition visits (29 to 42 days after giving birth) with East Nusa Tenggara resulting of 39.0-43.6 who performed a full postpartum visit and 10.4 percent had never had a postpartum examination (Kementerian Kesehatan R.I., 2018). The Ministry of Health emphasizes the availability of maternal health services in the community. The Government, East Nusa Tenggara with the maternal and child health revolutionary movement that is all pregnant women must give birth in adequate health facilities (Nassa, 2018). The postnatal period that is at risk for postpartum complications mainly occurs in the first 3 days after delivery. The coverage of postnatal health care for the first 3 days after delivery varies by province, which is highest in Yogyakarta (93.5\%) and lowest in Papua (54.9\%) and East Nusa Tenggara province 60.0 percent (Kementerian Kesehatan R.I., 2018). If the coverage of childbirth visits is not the same as the coverage of Nakes childbirth assistance, there will be possibility of uncontrolled 
puerperal complications, the wide distance between childbirth and postpartum visits results the greater risk of death (Kementerian Kesehatan R. I., 2014).

The highest number of maternal deaths is in East Sumba Regency with 19 maternal deaths, 12 of which are maternal deaths that occur during childbirth (Dinas Kesehatan Kabupaten Sumba Timur, 2018). The number of maternal deaths in 2015 there were 11 and 3 of them postpartum mothers, postpartum visit 3 was $87.4 \%$, in 2016 there were only 1 maternal mortality period, postpartum visit 3 of 88.6 percent and 2017 the number of maternal deaths was 9, 5 of them puerperal mothers, postpartum visits 3 by 91 percent (Nurrizka \& Wiko Saputra, 2013). This study aims to determine the quality of puerperal visits and the fulfillment of maternal needs during the puerperium in East Sumba district in 2015-2018. This study was conducted to develop knowledge, especially in maternal and neonatal emergency obstetric care regarding complications and illness in the puerperium and handling with theoretical conditions the latest and theoretical management. Practically to avoid risk factors to be able to prevent complications and diseases related to the puerperium in the mother so that the death of the puerperium does not occur due to factors that can be prevented.

\section{RESEARCH METHOD}

This type of research is a qualitative research with a phenomenological study that was digging up data to find meaning from the basic and essential things of the phenomenon, reality, or experience experienced by the object of research. In this case, it examined the scope of childbirth visits and the fulfillment of needs during the puerperium and the causes of death from mothers who died during childbirth to the midwife and her husband or family who live in one house. This research has been conducted in East Sumba Regency by taking samples of sub-districts and villages where maternal mortality occurred during the last 3 years, which was since 2016, 2017 and 2018. The process of collecting research data was conducted on September 11-15, 2018. The research site was the Primary Health Center (Puskesmas) area of Waingapu City, Kawangu, Melolo, Mangili, Lewa. Respondents in this study were families of postpartum mothers who died (husband, sister or in-laws) who understood the case of the postpartum mothers, implementing midwives at the Primary Health Center and coordinating midwives. The first step the researcher collected was data from the family of the deceased mother by visiting the mother's house and interviewed using a questionnaire that was prepared by the researcher. Researchers do data mining in the form of how object meaning gives meaning to related phenomena. Data mining is conducted by in-depth interviews with the object or informant in the study, as well as by making direct observations about how the research object interprets its experience to others. How to collect data through in-depth interviews with the family of the mother (husband/closest person) of the deceased mother regarding the fulfillment of postpartum maternal needs and causes of death and in-depth interviews with midwives who handle mothers since pregnancy, childbirth and postpartum for data on the coverage or quality of childbirth visits and fulfillment of postpartum maternal needs in relation to the roles and responsibilities of midwives and causes of postpartum maternal death using questions compiled by researchers.

Processing and analyzing data from Phenomenology studies as a methodology have three stages of synergizing processes. There are three steps in qualitative data processing, which are data reduction, data display, and conclusion drawing and verification, in implementing data reduction, data presentation, and drawing 
conclusions/verification. It is a step that very flexible, in the sense of not being bound by chronological boundaries. Overall these steps are interconnected during and after data collection. Data reduction, in this stage the researcher makes a selection, and focuses attention on simplification, abstraction, and transformation of the coarse data obtained. Presentation of data (data display), researchers develop a description of information arranged to draw conclusions and take action. Data display or data presentation commonly used in this step is in the form of narrative text. Conclusion drawing and verification, the researcher tried to draw conclusions and verify by looking for the meaning of each phenomenon he gets from the field, noting the regularities and configurations that might exist, the causal flow of the phenomena, and propositions.

\section{RESULTS AND DISCUSSION}

Initial respondent $\mathrm{N}$ said that her child was always diligent in conducting examinations during pregnancy. There were never complaints or the condition of a healthy mother during pregnancy until giving birth directly to the nearest Primary Health Center. After arriving at the Health Center, it turned out according to the Midwife it was better to give birth in a hospital so that it was referred to the Regional Public Hospital (RSUD) of Umbu Rara Meha Waingapu to give birth there. However, after arriving at the Umbu Rara Meha Waingapu Hospital, the midwife said it was not time to give birth so she was sent back on April 20. On April 21, his child felt pain in the abdominal area which increased so he went straight to the Lindimara Hospital (no longer at Umbu Rara Meha Waingapu Regional Hospital due to Disappointment on April 20). On April 22, the childbirth was delivered by Section Caeserea (SC) because labor did not progress and was suspected of poisoning pregnancy - blood pressure $140 / 90 \mathrm{mmHg}$ and accompanied by seizures. The baby is born healthy and safe. The third day of childbirth, the mother experienced another seizure and was unconscious until death without knowing what the exact diagnosis was. During the 3 day postpartum period the mother was under the supervision of midwives and doctors.

Based on the explanation of the respondents above, it is clear that the quality of the puerperal visit is good, all elements are well checked, systematically, because it is conducted with strict monitoring by both midwives and doctors. In connection with this, we made confirmation to the Coordinating Midwife and Village Midwife who cared for the postpartum mother. The result was that they confirmed that the postpartum mother was indeed diligent in conducting pregnancy examinations and no danger signs were found until the time of delivery. When they were about to give birth, they found blood pressure of 140/90 $\mathrm{mmHg}$ and immediately had a seizure so that cyto was immediately operated for the safety of the fetus and also the mother. After giving birth, they also conduct regular and systematic visits and examinations, but the third day of the puerperium experienced seizures, was unconscious and finally died on the fourth day of the puerperium. Based on the results of interviews with the village midwife, Coordinator and Midwife said the cause of death according to the doctor's diagnosis was Eclampsia.

Respondent with the initials ND said that "during pregnancy, there was no pregnancy checkups or were visited by midwives, until the time of delivery said headaches and seizures suddenly, so immediately asked for help from neighbors to deliver to the hospital, finally giving birth by surgery, the baby was born healthy and safe, mother had regained consciousness and stopped seizures, then, returning to the third day of puerperal home. The seventh day experienced the same complaint when 
they were about to give birth, which was a headache and suddenly had a seizure. He asked the neighbor to help to take him to the hospital, but his life was not helped and died on the way. Based on the results of the above interview, it was concluded that pregnant women did not carry out antenatal care and postpartum visits so that danger signs were not detected. The researcher followed up with an interview with the Coordinating Midwife, with the following results:

"The pregnant woman mentioned above is the responsibility of the Midwife in the Village and has been informed to the Village Midwife to collect data, examine all pregnant women and post-partum mothers in the work area and report monthly during monthly meetings at the Primary Health Center and must visit if pregnant or postpartum mothers are not make a visit to a health care facility. Puerperal visits conducted 3 times because they are still applying the old theory, the village midwife while attending the Educational Learning Recognition program (RPL) so that the theory has been updated but the midwife is not doing her job properly'".

The interview finally continued with the village midwife, the results were as follows:

"The midwife said that she did not know that her patient was pregnant, her family and neighbors also did not know that ND's wife was pregnant, and indeed no one reported to me so I also never made a home visit to record and examine her pregnancy and not too make a postpartum visit ". In conclusion, ND pregnant women did not visit the puerperium and were not visited by the Midwife until she died with Eclampsia Post Caesarean section. Researchers continued interviews with respondents with the initial $\mathrm{KR}$, with the following results:

"Mother KR gave birth on June 25, 2018 by way of surgery is 'expensive'/the first child after more than 10 years of marriage, contractions of the uterus were flabby, the baby was born healthy and safe, and so was his mother. The fourth day of mother's postpartum period was discharged with her baby. The postpartum visit was conducted regularly, even the midwife also comes to visit the house until July 4 when the midwife visits says there was a smelly discharge coming out of the birth canal so that it must be referred to the hospital for examination. However, they did not go to the hospital, so the Midwife came back to the house on July 6 and immediately took her to the hospital. On July 7, KR's mother suffered a seizure and finally died in the hospita'.

The conclusion from the interview is that the coverage of puerperal visits is good, but in terms of quality it is lacking because midwives are unable to detect the danger signs of the puerperium ie early puerperal infection. The interview continued with the Coordinating Midwife and Village Midwife who handled the postpartum mother, the result of the interview was as follows:

"We have conducted puerperal visits and regular and systematic examinations, in fact we have recommended to immediately go to the hospital when we find a foulsmelling lokhea removal, but the person is not going to the hospital so we immediately take him to the hospital 2 days later, however it's too late, the doctor said it was puerperal sepsis."

The conclusion from the interview above is that the midwife has visited in quantity but is of poor quality, so that she has found an infection at an advanced stage, and lacks understanding of the case referral system so that she will leave the puerperal woman with her family to go to the hospital, although she will eventually accompany her after 2 days not home, sick, but it was too late so the patient did not get the right help to prevent the death of the mother KR. 
The results of interviews with respondents with the initial EN are as follows:

"Mrs. EN gave birth in the hospital normally, conducted regular puerperal visits to the Primary Health Center but on the $12^{\text {th }}$ day of the puerperium, she complained of bleeding from the birth canal so that she went to the Primary Health Center, the midwife said there might be leftovers in the womb so we had to do a curette. We agree only but eventually died in hospital due to infection said midwife."

It shows that the Midwife in quantity has visited and examined the puerperium but in quality that is still lacking, who cannot detect early signs of infection. Moreover, there is a suspicion of leftover placental remains and only known after the puerperal visit 2 ( 2 weeks postpartum). After interviews with families, the Coordinating Midwife and the Village Midwife, the researcher conducted interviews using questionnaires to the Midwives in the areas of the Primary Health Center of Waingapu, Kawangu, Melolo, Mangili and Lewa to find out the quality of childbirth visits and fulfillment of postpartum needs totaling 30 Respondents. The results are as follows:

\section{a. Quality of Postpartum Visits}

Most respondents said that they conducted postpartum examinations regularly with a frequency of visits 4 times, but there were still those who conducted postpartum visits less than 4 or even less than 2 times for reasons far, damaged roads, could not be reached by two-wheeled vehicles, the additional duties of a Midwife are more than the main duties of a Midwife. Puerperal examination conducted systematically head to toe but not focused, which only measures vital signs only, other things are only asked, not touched, touched or examined especially the breast, abdomen and birth canal, and some even do direct examination on the area abdomen and birth canal but even then it is incomplete and out of focus. This is the reason why early childbirth problems are not detected.

All respondents gave counseling about danger signs but were very superficial, signs and symptoms were incomplete so patients did not understand and half of the respondents did not provide routine counseling at each postpartum visit. Respondents also did not provide information about the procedure for childbirth referral so that there were patients who died because they were late being referred or referred to at an advanced stage. Based on the above results, it can be concluded that the quality of the postpartum visit is still lacking because it is irregular, not systematic, incomplete and not focused.

b. Meeting the needs of the puerperium

Meeting the needs of the childbirth include: 1). Personal hygiene which is all respondents provide information but do not pay attention or evaluate the results at each subsequent visit because they do not check only ask the patient. For rest, all are fulfilled, there is no problem with time off but for practice all respondents do not teach patients. Nutritional needs, all respondents only provided information about eating a lot but it was not clear the amount, type and type of food eaten and drunk, nor did they use media and examples of existing local ingredients. 2). Breastfeeding and caring for breasts ie respondents convey information about breastfeeding exclusively and caring for breasts but most do not evaluate the next postpartum visit. She does not check the state of the breasts, nipples, cleanliness associated with the milk needs of breastfed babies. 
According to Hamidiyanti, (2019), the ability of adolescent primiparous postpartum mothers is very influential in breastfeeding newborns, so it needs clearer information. Rahmawati et al., (2019), also argued that there is an increase in knowledge about postnatal maternal nutrition when delivering information using the media so that the provision of information about nutrition should be clear, because meeting the nutritional needs of the mother during the breastfeeding period or period is very important this is in accordance with the results of research conducted by Mali, et al., (2014), which stated that postpartum mothers need to meet the nutritional needs in improving the recovery of good conditions after giving birth. Foods that are consumed during childbirth are types of foods that contain four healthy five perfect including fish, eggs, meat, milk, water, vegetables, rice and fruits. If a mother does not consume food that is in accordance with the four healthy five perfect conditions, it will impact the mother to be deficient in nutrients so that wound healing will take longer to heal, even infection will occur, and the process of involution and reduced production of breast milk and at the same time help wound recovery perineum (Rahmawati, E. \& Triatmaja, N, 2015). Despite the fact according to the results of Sundari, et al., (2013) terhadap 52 responden, 35 responden $(67,3 \%)$ research on 52 respondents, 35 respondents $(67.3 \%)$ postpartum mothers already knew about the nutritional needs of the puerperium correctly such as the consumption of many foods containing protein and enough fluids, but there are still many diatara those who abstain from eating because of the influence of culture and attitudes that are not modern and use the old culture of ancestors. The results of Mota, et al., (2015) also said that the behavior of fulfilling the needs of breastfeeding mothers differ according to ethnicity or culture.

Need for Intercourse: Information about sexual intercourse needs after giving birth has been given by the Midwife during the postpartum visit and found no problems relating to marital relations after giving birth. Contraception: given information about the importance of post-copy contraception but not given proper counseling early on about the type of contraception, the disadvantages and advantages of each contraceptive, counseling without media or props. Thus, it can be concluded that the fulfillment of postpartum maternal needs is still lacking. Masita, E. D., (2016) explained that the sexual function of the puerperal mother is related to the knowledge factor so information must be clearly given to the mother even though there is no relationship problem between husband and wife.

The Vision of the Government of East Sumba Regency, The Public Health Office is the main driver for the realization of an independent, quality, fair and equitable public health development with one of its missions to increase efforts to prevent, eradicate and overcome health problems and to improve quality, equitable and affordable public health services (Dinas Kesehatan Kabupaten Sumba Timur, 2015). To achieve this vision and mission, one of the goals of health development in East Sumba Regency is an increase in maternal, infant and family planning health services. That is the main task for the Midwife. In connection with this, the Midwives must be able to provide quality services, especially in childbirth services, where the puerperium begins after the placenta born and ends when the uterine returns as before pregnancy, lasts for about 6 weeks for approximately 4 (four) times with the following details: $1^{\text {st }}$ puerperal visit 6-8 hours after delivery (before returning): $2^{\text {nd }}$ puerperal visit 6 days after delivery: $3^{\text {rd }}$ puerperal visit 2 weeks after delivery and: puerperal visit 4-6 weeks after delivery. Thus, Midwives will be able to prevent, eradicate and overcome postpartum maternal health problems as early as possible so that in the end, it can reduce morbidity and 
mortality rates for mothers and babies in East Sumba Regency (Kementerian Kesehatan, 2018); (Kementerian Kesehatan R.I., 2013).

The results showed that Case $\mathrm{N}$ performed regular Antenatal Care and did not find any danger signs but before delivery became a seizure with blood pressure 140/90 $\mathrm{mmHg}$ so that gave birth by cesarean section but finally died on the third day of childbirth with a diagnosis of eclampsia. This is consistent with the fact that more than $90 \%$ of maternal deaths are due to obstetric complications which are often unpredictable during pregnancy. Most of the complications that occur during or around delivery are many of the mothers who are not categorized as at risk, apparently experiencing complications and vice versa. Among mothers who are categorized as at risk, it turns out that labor takes place normally. Therefore, the recommended approach is to consider all pregnancies at risk and every pregnant woman to have access to safe delivery assistance and obstetric services. It is estimated that $15 \%$ of pregnancies will experience high risk conditions and obstetric complications, which can endanger the lives of both mother and fetus if not handled adequately (Awang, 2017); (Rahayuningsih, 2013); (Istiana, et al., 2018).

The roles and responsibilities of midwives during childbirth are: a. Detect complications and the need for referral, b. Provide counseling for mothers and their families on how to prevent bleeding, recognize danger signs, maintain good nutrition, and practice safe hygiene, c. Facilitating relationships and inner bonds between mother and baby and d. Starting and encouraging breastfeeding (Permenkes RI, 2013). The puerperium is divided into 3 stages, namely: a. Puerperium early is recovery where the mother has been allowed to stand and walk around. b. Intermedial puerperium is a period in which recovery of reproductive organs for about six weeks c. Remote puerperium is the time needed to recover and be perfectly healthy, especially if the mother during pregnancy or time of delivery has complications (Permenkes RI, 2017).

National program policies during the postnatal period that is at least 4 visits during the postpartum period, with the aim to: a. Assess the health condition of the mother and baby b. Conduct precautions against the possibility of health problems for the puerperal mother and her baby c. Detect any complications or problems that occur during childbirth, and d. Handling complications or problems that arise and disrupt the health of postpartum mothers and their babies (Permenkes R.I., 2017); (Kementerian Kesehatan R.I., 2013).

The results of the study found that 40 percent of childbirth examinations or visits less than 4 or even less than 2 times by reason of distant, damaged roads cannot be reached by two-wheeled vehicles, midwife additional tasks more than the main task as a midwife. The reason the road is damaged and cannot be reached by vehicle is in accordance with the condition of the topography of East Sumba in general flat (in coastal areas), sloping to bumpy (lowland areas) and hilly (mountains), but this should not be used as an excuse not to visit the mother childbirth because as a midwife has the obligation to conduct childbirth visits 4 times, especially if the puerperal mother finally died due to detection of early signs of dangers and unable to cope with health problems experienced by the puerperal mother, this violates the authority as a midwife and the right of patients to get help (Zimmerman et al., 2019). There is a relationship between postpartum maternal activity and quality of life for postpartum mothers (Rahayuningsih, 2013).

Meanwhile, if they do not visit postpartum mothers regularly and complete with reasons because the additional tasks are more than the basic tasks then this is considered 
negligent because in the implementation of Midwifery Practices, Midwives have the authority to provide maternal health services as stated in article 18, and article 19 health services the mother as referred to in paragraph (1) shall fault the normal postpartum maternal service. Also in article 28, it is stated that in conducting its midwifery practices, the Midwife is obliged to: a. respect the rights of patients; b. provide information about patient health problems and services needed; c. refer to cases that are not within their authority or cannot be handled in a timely manner (Zimmerman et al., 2019). In connection with the explanation above, there is no reason not to conduct postpartum visits by taking the right actions.

Sixty percent or 18 respondents said that they conducted regular examinations with a frequency of visits 4 times, this was in accordance with the target coverage of childbirth visits of 4 times, but 70 percent of childbirth examinations were conducted systematically head to toe but not focused, which only measured signs vital signs only, other things are only asked, not looked at, touched or examined especially the breast, abdomen and birth passages and 30 percent direct examination of the abdominal area and birth canal but that too is incomplete and unfocused. This is what causes no danger signs to be detected the puerperium from an early age, because the examination of the puerperium must be done regularly, systematically and focus on the face ie the eyes (conjunctiva, sclera), edema, mouth and teeth, breasts (putting milk, milk removal, there are no signs of infection such as swelling, red, pain and heat, blisters), abdomen (high uterine fundus, uterine contractions), perineum (perineal conditions there are sores or not, there are signs of infection in the form of redness, swelling and pain), vaginal discharge in the form of blood or lochea that smells or is normal according to the age of the puerperium), lastly the upper and lower extremities whether there are edema and varicose veins or other infections (Permenkes RI, 2017). Especially for patients who give birth by cesarean section there are differences in the quality of life of postpartum based on the type of labor because the results of the study above occurred in nursing mothers with cesarean delivery (Nisak \& Rahayuningsih, 2018); (Rahmawati et al., 2019); (Istiyati, et al., 2014).

The results also showed that 100 percent of midwives gave counseling about danger signs but were very superficial, signs and symptoms were incomplete so patients did not understand and 50 percent were not given routine counseling at each postpartum visit. This is in accordance with the cases experienced by EN, where midwives always visit but because counseling is incomplete and unfocused, the patient is detected late and is late referred so that he eventually dies with puerperal sepsis in the hospital. The results of the study, (Situmorang, et al., 2016) said that there was a significant relationship between knowledge and the incidence of preeclampsia, meaning that by having knowledge about their health they could know and overcome the signs and symptoms as well as how to overcome the health problems that accompanied their pregnancy, so they were not anxious in facing pregnancy and immediately report to the health worker if there are health problems that accompany the pregnancy. Mother's knowledge about preeclampsia and eclampsia is very important because almost $50 \%$ of maternal and fetal deaths are caused by preeclampsia and eclampsia, so it is important for pregnant women to know about preeclampsia as early as possible (Situmorang, et al., 2016); (Eldawati, 2015) and there are also some the relationship between knowledge and the number of pregnancies or parity of the mother (Masita, E. D., 2016). Puerperal infection or sepsis is a major cause of maternal death in developing countries. higher than normal labor. The main germs in puerperal infections due to cesarean section are 
Escherichia coli, Streptococci sp., Anaerobic microorganisms (bacteroides, gonococci), and Chlamydia trachomatis (relatively mild symptoms). In addition to fever (temperature increase > 38 degrees Celsius), another symptom of postpartum infection is pain in the lower abdomen (uterus) (Istiyati, et al., 2014) Usually this puerperal infection is endometritis, or perhaps more precisely is metritis. Antibiotics are the main action, in addition to measures to prevent childbirth infection with a clean (sterile) and safe delivery. In some countries there is a relationship between deliveries assisted by TBAs with a high incidence of puerperal infections.One of the most dangerous causes of postpartum infection and cause death is Group A Streptococcus or Streptococcus pyogenes Streptococcal Toxic Shock Syndrome (Strep TSS), is a dangerous syndrome caused by toxic substances (endotoxins) from this Group A Streptococcal bacteria (Msovela \& Tengia-Kessy, 2016).

Eclampsia is the third leading cause of maternal death worldwide. Mothers with childbirth followed by severe eclampsia or pre-eclampsia should be hospitalized. Therefore, blood pressure checks should be routinely performed on pregnant women, considering that hypertension can occur in pregnancy, especially if the gestational age is above 20 weeks. In Europe and other developed countries, eclampsia is estimated to occur in 1 in 2000 deliveries. Some cases of eclampsia occur a few days after delivery. Some studies report that more than $50 \%$ of eclampsia occurs on the third or more postpartum days. Pre-eclampsia and eclampsia that occur after childbirth are very rare, where the puerperal mother will experience hypertension and increased protein levels in the urine (proteinuria), after delivery. Usually eclampsia and pre-eclampsia are experienced since pregnancy, mostly in the third trimester of pregnancy (Situmorang, et al., 2016) Based on the results of research conducted at Prof. RSUP Dr. R. D. Kandou Manado, severe preeclampsia and eclampsia occur mostly in the age group of 20-35 years, the number of parities in primipara, without a history of hypertension, and without multiple pregnancy. In severe preeclampsia is mostly accompanied by obesity, and in eclampsia not found underweight. The results of the study show that 80 percent of informants are of healthy reproductive age (Awang, 2017); (Sumampouw, et al., 2019); (Rachmawati, 2004).

\section{CONCLUSION}

The high coverage of puerperal visits is not followed by the quality of puerperal visits, where there are still puerperal examinations conducted by midwives who are irregular, unsystematic and unfocused so they are unable to detect postpartum problems early. Meeting the needs of mothers during childbirth is also lacking because only convey incomplete information, not detailed and do not routinely carry out checks during puerperal visits so that the puerperal mother lacks understanding and does not do it correctly, still problems arise after childbirth infection due to lack of attention to local hygiene genetalia during puerperal visits.

\section{REFERENCES}

Abdullah, A. (2015). Faktor risiko kematian neonatal di provinsi Nusa Tenggara Timur: a matched case-control study. Australia Indonesia Partneership for Maternal and Neonatal Health.

Affandi. (2019). Buku Panduan Praktis Pelayanan Kesehatan Maternal dan Neonatal. Jakarta: Yayasan Bina Pustaka Sarwono Prawirohardjo. 
Awang, M. N. (2017). Kajian Kematian Ibu berdasarkan Kategori ANC, Kategori Risiko Tinggi dan Rujukan Kasus Risiko Tinggi di Kabupaten Sumba Timur Tahun 2011-2015. Jurnal Info Kesehatan, 15(1), 110-125.

Dinas Kesehatan Kabupaten Sumba Timur. (2018). Laporan Jumlah Kematian ibu, Bayi dan Balita 2014 sampai tahun 2018. Sumba Timur: Dinas Kesehatan Kabupaten Sumba Timur.

Dinas Kesehatan Kabupaten Sumba Timur, 2015, Kebijakan Pembangunan bidan kesehatan ibu dan anak, Sumba Timur

Eldawati, S. (2015). Hubungan Pengetahuan dan Sikap Ibu Nifas dengan Praktik Perawatan Masa Nifas di Kecamatan Gunungpati Kota Semarang Bulan Januarimaret 2015. Jurnal Kesehatan Masyarakat (e-Journal), 3(3), 228-237.

Hamidiyanti, B. Y. F. (2019). Kemampuan Ibu Postpartum Primipara Remaja Dalam Menyusui Bayi Baru Lahir di Wilayah Kerja UPT BLUD Puskesmas Narmada Kabupaten Lombok Barat NTB 2017. Jurnal Midwifery Update (MU), 1(1), 1827.

Imaroh, I. I., Nugraheni, S. A., \& Dharminto, D. (2018). Faktor Risiko Yang Mempengaruhi Kejadian Hiperensi Pada Ibu Hamil Di Wilayah Kerja Puskesmas Kedungmundu, Kota Semarang Tahun 2017. Jurnal Kesehatan Masyarakat (eJournal), 6(1), 570-580.

Istiyati, S., Haryanto, S., \& Subandono, J. (2014). Pelaksanaan Discharge Planning Pada Pasien Post Sectio Caesaria. Jurnal Kebidanan dan Keperawatan,10 (2), 103-114.

Kementerian Kesehatan R. I. (2014). Mother's Day: Situasi Kesehatan Ibu. Jakarta: Publikasi Pusat Data dan Informasi. Kementerian Kesehatan RI.

Kementerian Kesehatan R.I., (2013). Buku Saku Pelayanan Kesehatan Ibu Di Fasilitas Kesehatan Dasar Dan Rujukan, Pedoman Bagi Tenaga Kesehatan, Edisi Pertama, Jakarta

Kementerian Kesehatan R.I. 2018. Riset Kesehatan Dasar (Riskesdas). Jakarta: Badan Litbangkes

Masita, E. D. (2016). Pengaruh Tingkat Pengetahuan, Paritas, Jenis Persalinan, Jenis Pekerjaan Terhadap Fungsi Seksual Ibu Nifas. Journal of Health Sciences, 9(2), 159-167.

Mali, A. M. B., Gunawan, I. M. A., \& Sumarni, S. (2014). Nutrient Fulfillment Of Mothers During Puerpurium Period In The Se'i Culture At Subdistrict Of Molo Selatan District Of Timor Tengah Selatan. Jurnal Info Kesehatan, 12(1), 639-648.

Mota, K., Reddy, S., \& Getachew, B. (2015). Unmet need of long-acting and permanent family planning methods among women in the reproductive age group in shashemene town, Oromia region, Ethiopia: a cross sectional study. BMC women's health, 15(1), 51. Doi: https://doi.org/10.1186/s12905-015-0209-y

Msovela, J., \& Tengia-Kessy, A. (2016). Implementation and acceptability of strategies instituted for engaging men in family planning services in Kibaha district, Tanzania. Reproductive health, 13(1), 13(1), 1-9. Doi: https://doi.org/10.1186/s12978-016-0253-6

Nassa, M. (2018). Analisis program revolusi kesehatan ibu dan anak dan dampaknya terhadap penurunan angka kematian ibu dan bayi. Berita Kedokteran Masyarakat, 34(11), 9-8. 
Nisak K., \& Rahayuningsih F., B. (2018). Perbedaan Kualitas Hidup Postpartum Berdasarkan Jenis Persalinan Di Rsud Dr. Soeratno Gemolong. Prosiding Seminar Nasional seri 8, $89-100$

Nurrizka, R. H., \& Saputra, W. (2013). Arah dan Strategi Kebijakan Penurunan Angka Kematian Ibu (AKI), Angka Kematian Bayi (AKB) dan Angka Kematian Balita (AKABA) di Indonesia.Jakarta: Prakarsa Policy Update Public Health.

Permenkes R.I. (2013). Peraturan tentang Pelayanan Masa Nifas. Jakarta: Kementerian Kesehatan Republik Indonesia.

Permenkes R.I. (2017). Peraturan tentang Izin dan Penyelenggaraan Praktik Bidan. Jakarta: Kementerian Kesehatan Republik Indonesia.

Rachmawati, I. N. (2004). Hipertensi Pada Kehamilan: Analisis Kasus. Jurnal Keperawatan Indonesia, 8(1), 30-35.

Rahmawati, E., \& Triatmaja, N. T. (2015). Hubungan Pemenuhan Gizi Ibu Nifas Dengan Pemulihan Luka Perineum. Jurnal Wiyata: Penelitian Sains dan Kesehatan, 2(1), 19-24.

Rahmawati, R. S. N., Suwoyo, S., \& Putri, S. F. (2019). Peningkatan Pengetahuan Tentang Nutrisi Ibu Nifas Menggunakan Media Aplikasi "Sinnia" Di Rumah Sakitaura Syifa Kediri. Jurnal Kebidanan Kestra (JKK), 2(1), 18-27.

Rahayuningsih, F. B. (2013) Hubungan Aktivitas Ibu Nifas Dengan Kualitas Hidup Ibu Nifas Di Wilayah Puskesmas Miri Sragen. Prosiding Seminar Nasional \& Internasional, 37-40.

Situmorang, T. H., Damantalm, Y., \& Januarista, A. (2016). Faktor-faktor yang berhubungan dengan kejadian Pre Eklampsia pada Ibu Hamil di Poli KIA RSU Anutapura Palu. Healthy Tadulako Journal (Jurnal Kesehatan Tadulako), 2(1).3444.

Sumampouw, C. M., Tendean, H. M., \& Wagey, F. W. (2019). Gambaran Preeklampsia Berat dan Eklampsia Ditinjau dari Faktor Risiko di RSUP Prof. Dr. RD Kandou Manado. Jurnal Medik dan Rehabilitasi, 1(3), 1-5.

Sundari, A., Sapartinah, T., \& Mursiti, T. (2019). Gambaran Tingkat Pengetahuan Ibu Nifas Tentang Nutrisi Masa Nifas Di Wilayah Puskesmas Ringinarum Kabupaten Kendal Tahun 2013. Midwifery Care Journal, 1(1), 32-38.

Zimmerman, L. A., Yi, Y., Yihdego, M., Abrha, S., Shiferaw, S., Seme, A., \& Ahmed, S. (2019). Effect of integrating maternal health services and family planning services on postpartum family planning behavior in Ethiopia: results from a longitudinal survey. BMC public health, 19(1), 1-9. Doi: https://10.1186/s12889019-7703-3. 